\title{
Isolation and characterization of eight polymorphic microsatellite markers from the orange-fin anemonefish, Amphiprion chrysopterus
}

\author{
Ricardo Beldade $\cdot$ Sally J. Holbrook $\cdot$ \\ Russell J. Schmitt $\cdot$ Serge Planes $\cdot$ Giacomo Bernardi
}

Received: 6 August 2009/Accepted: 10 August 2009/Published online: 19 September 2009

(c) The Author(s) 2009. This article is published with open access at Springerlink.com

\begin{abstract}
Eight polymorphic microsatellite loci were isolated and characterized from the orange-fin anemonefish (Amphiprion chrysopterus). These loci provided markers with polymorphisms of 4-14 alleles per locus within 151 individuals from Moorea, French Polynesia. The expected heterozygosities ranged from 0.53 to 0.88 . High variability suggests that these markers should be useful to study paternity, population structure, and connectivity in this species.
\end{abstract}

Keywords Amphiprion chrysopterus . Orange-fin anemonefish · Microsatellite

A common strategy to promote sustainability and conserve biodiversity on marine reefs involves the design and creation of spatially defined protected areas (Cowen et al. 2007). Crucial for the implementation of this and other

R. Beldade $(\bowtie) \cdot G$. Bernardi

Department of Ecology and Evolutionary Biology,

University of California Santa Cruz, 100 Shaffer Road,

Santa Cruz, CA 95060, USA

e-mail: ricardobeldade@yahoo.com; rbeldade@gmail.com

S. J. Holbrook · R. J. Schmitt

Coastal Research Center, Marine Science Institute, University

of California Santa Barbara, Santa Barbara, CA 93106, USA

S. J. Holbrook - R. J. Schmitt

Department of Ecology, Evolution, and Marine Biology,

University of California Santa Barbara, Santa Barbara,

CA 93106, USA

S. Planes

UMR 5244, CNRS-EPHE-UPVD, Centre de Biologie et d'Ecologie Tropicale et Méditerranéenne, Université de Perpignan, 66860 Perpignan Cedex, France management actions is the accurate knowledge of dispersal, self-recruitment, and connectivity among populations (Hauser and Carvalho 2008). Anemonefishes in the genus Amphiprion have been used as model species for such studies.

The largest species of Amphiprion, the orange-fin anemonefish A. chrysopterus, occurs in the central and western Pacific from French Polynesia to Micronesia, Papua New Guinea and the Philippines (Fautin and Allen 1997). As with most other anemonefish, reef-associated life stages of A. chrysopterus live on anemones from the moment larvae settle from the plankton (Fautin and Allen 1997). The ease with which various developmental stages can be sampled has enabled the use of anemonefishes in studies of dispersal and self-recruitment (e.g. Jones et al. 2005). Orange-fin anemonefish have been used in explorations of population and community dynamics (e.g., Schmitt and Holbrook 2003; Holbrook and Schmitt 2004), although issues related to connectivity and self-recruitment in this otherwise well studied species have not been resolved. The main goal of this study was to develop and characterize microsatellite markers from Amphiprion chrysopterus, to enable future behavioral and population genetic studies.

Total DNA was extracted using a DNeasy blood and tissue kit (QIAGEN) from approximately $20 \mathrm{mg}$ of caudal fin. Genomic DNA (100 $\mu \mathrm{g})$ was used by GIS (Genetic Identification Services, Chatsworth, California) to identify microsatellite loci. Genomic libraries were enriched for CA, CATC, TACA, TAGA repeat motifs. We tested 18 microsatellites for polymorphism. Amplification reactions were carried out using a fluorescently blue labeled forward primer and an unlabeled reverse primer in an Applied Biosystems GeneAmp PCR 9700 system in a total volume of $13 \mu \mathrm{l}$ containing $11 \mu \mathrm{l}$ of $1.1 \mathrm{PCR}$ Mastermix $(25 \mathrm{mM}$ TAPS pH 9.5, $50 \mathrm{mM} \mathrm{KCl,} 2 \mathrm{mM} \mathrm{MgCl}_{2}, 200 \mu \mathrm{M}$ each 
Table 1 Characterization of eight polymorphic microsatellite loci for the orange-fin anemonefish, Amphiprion chrysopterus for 151 specimens

\begin{tabular}{|c|c|c|c|c|c|c|c|c|}
\hline Locus & Primer sequence $\left(5^{\prime}\right.$ to $\left.3^{\prime}\right)$ & Repeat & $\mathrm{Ta}$ & $\mathrm{Na}$ & As & RR (bp) & Ho $(\mathrm{He})$ & GenBank \\
\hline ACRY_A115 & $\begin{array}{l}\text { F: GACTCGTGTTCGGAGGAC } \\
\text { R: CGGGATAATAACGGAGAGC }\end{array}$ & $(\mathrm{CA})_{27}$ & 57 & 12 & 228 & $212-242$ & $0.69(0.77)$ & GQ454916 \\
\hline ACRY_A130 & $\begin{array}{l}\text { F: GCACTCAACACAAAGACCTTA } \\
\text { R: ACCCAAACAACATCCAGTC }\end{array}$ & $(\mathrm{CA})_{24}$ & 57 & 12 & 167 & $160-194$ & $0.79(0.82)$ & GQ454917 \\
\hline ACRY_A131 & $\begin{array}{l}\text { F: CCTCAGCAGTGTGAAATGA } \\
\text { R: CTCCACCTCTCTCTTCTTGAC }\end{array}$ & $(\mathrm{CA})_{39}$ & 57 & 13 & 226 & $200-250$ & $0.74(0.81)$ & GQ454918 \\
\hline ACRY_CF11 & $\begin{array}{l}\text { F: GCTGGTTACAACACCTTG } \\
\text { R: GTAATTGCTGCAAGACAG }\end{array}$ & $(\mathrm{CT})_{15}(\mathrm{CA})_{16}$ & 60 & 8 & 198 & $180-206$ & $0.71(0.69)$ & GQ454919 \\
\hline ACRY_D1 & $\begin{array}{l}\text { F: CCAAAAGTTTAGGAAGCTACC } \\
\text { R: AACCAGACTGCCCTGATAC }\end{array}$ & $(\mathrm{GATA})_{25}$ & 57 & 13 & 325 & $273-341$ & $0.78(0.78)$ & GQ454920 \\
\hline ACRY_D103 & $\begin{array}{l}\text { F: GTTGGCTAATGGTGCTGTG } \\
\text { R: GATTCTGTGGTGGCATCAG }\end{array}$ & $(\text { GATA })_{13}$ & 57 & 4 & 247 & $239-251$ & $0.84(0.88)$ & GQ454921 \\
\hline ACRY_D108 & $\begin{array}{l}\text { F: GAAGGATGTGCTTTGTTGTTC } \\
\text { R: GCTTTACGATTTTACAATGCAC }\end{array}$ & $(\mathrm{GATA})_{30}$ & 57 & 14 & 296 & $286-338$ & $0.53(0.53)$ & GQ454922 \\
\hline ACRY_D114 & $\begin{array}{l}\text { F: TGTTCCAGCTCTGATATTTGAC } \\
\text { R: TTGGCAGTGTTTTATACCTGTC }\end{array}$ & $(\text { GATA })_{19}$ & 57 & 11 & 245 & $205-285$ & $0.72(0.76)$ & GQ454923 \\
\hline
\end{tabular}

Columns correspond to: microsatellite name (locus), primer sequence, $(\mathrm{F})$ forward and $(\mathrm{R})$ reverse primers, repeat motif, annealing temperature in degrees centigrade (Ta), number of alleles per locus (Na), amplification size of original clone (As), repeat size range in bp (RR), (Ho) observed and $(\mathrm{He})$ expected heterozygosities and GenBank accession numbers. All microsatellites were tagged with blue fluorescent dye (from SigmaAldrich). All individuals were genotyped successfully except for D1 (two samples did not amplify)

dNTP, Taq $5 \mathrm{u} / \mu \mathrm{l}$, Thermo Scientific), $0.2 \mu \mathrm{M}$ primers and approximately $2 \mathrm{ng}$ of DNA template. The following temperature profile was used: $3 \mathrm{~min}$ at $94^{\circ} \mathrm{C}$, followed by 35 cycles of $30 \mathrm{~s}$ at $94^{\circ} \mathrm{C}$ for $40 \mathrm{~s}, 55-58^{\circ} \mathrm{C}$ for $40 \mathrm{~s}, 72^{\circ} \mathrm{C}$ for $40 \mathrm{~s}$ and a final extension of $72^{\circ} \mathrm{C}$ for $4 \mathrm{~min}$. Each microsatellite amplification was diluted with $n \mathrm{H}_{2} \mathrm{O}(1: 20)$, mixed with Applied Biosystems GeneScan 500 ROX and size standard, run on an ABI 3100 automated sequencer, and scored using the software GENEMAPPER version 3.7 (Applied Biosystems). We scanned our data for null alleles using MICROCHECKER (van Oosterhout et al. 2006), for each locus, calculated expected and observed heterozygosities, deviations from Hardy-Weinberg (HW) equilibrium and presence or absence of linkage disequilibrium using ARLEQUIN version 3.11 (Excoffier et al. 2005).

Four out of 15 microsatellites studied were found to be monomorphic and three others gave low amplification success. Table 1 summarizes the characteristics of the eight primer pairs of polymorphic loci developed from the orange-fin anemonefish. From a sample of 151 individuals collected in Moorea, all loci gave 100\% successful amplifications except for locus D1 for which two samples were not amplified successfully. The number of alleles ranged from 4 to 17 per locus. No significant linkage disequilibrium was observed for any pair of loci $(P>0.05$ for all comparisons). There was no evidence of null alleles for any of the markers. The large majority conformed to HW equilibrium except for A115. This result may be due to selection, reduction of gene flow, or other sources of pressure such as extensive population fluctuations.

Acknowledgments This research was supported by grant OCE 0417412 from the National Science Foundation and an award from the Gordon and Betty Moore Foundation. R. Beldade also was funded by FCT (SFRH/BPD/26901/2006). This is a contribution of the Moorea Coral Reef (MCR) Long Term Ecological Research (LTER) site, and is contribution number 179 of the UC Berkeley Gump Research Station.

Open Access This article is distributed under the terms of the Creative Commons Attribution Noncommercial License which permits any noncommercial use, distribution, and reproduction in any medium, provided the original author(s) and source are credited.

\section{References}

Cowen RK, Gawarkiewicz G, Pineda J, Thorrold SR, Werner FE (2007) Population connectivity in marine systems: an overview. Oceanography 20:14-21

Excoffier L, Laval G, Schneider S (2005) Arlequin version 3.0: an integrated software package for population genetics data analysis. Evol Bioinform Online 1(4):7-50

Fautin DG, Allen GR (1997) Field guide to anemone fishes and their host sea anemones. Western Australian Museum, Perth

Hauser L, Carvalho G (2008) Paradigm shifts in marine fisheries genetics: ugly hypotheses slain by beautiful facts. Fish Fish 9:333-362

Holbrook SJ, Schmitt RJ (2004) Population dynamics of a damselfish: effects of a competitor that also is an indirect mutualist. Ecology 85:979-985 
Jones G, Planes S, Thorrold S (2005) Coral reef fish larvae settle close to home. Curr Biol 15:1314-1318

Schmitt RJ, Holbrook SJ (2003) Mutualism can mediate competition and promote coexistence. Ecol Lett 6:898-902 van Oosterhout CD, Weetman D, Hutchinson WF (2006) Estimation and adjustment of microsatellite null alleles in non-equilibrium populations. Mol Ecol Notes 6:255-256 